\title{
Trade-Based Money Laundering (TBML) \\ Empowers Criminals to Run Free post-Brexit \\ Mariola Jolanta Marzouk
}

\section{Contents}

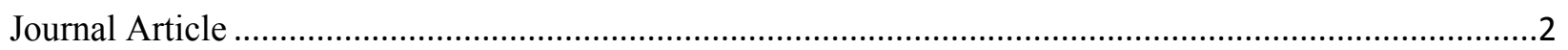

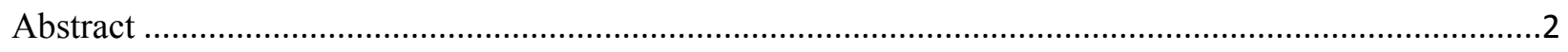

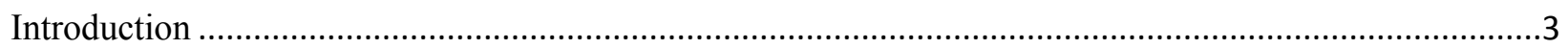

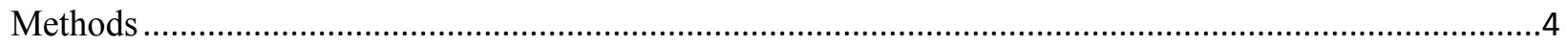

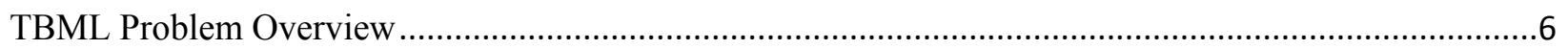

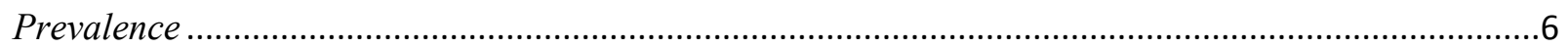

Susceptible Industries and Businesses with Particular Focus on Fishing .........................................6

Susceptible Trade Finance Products with Particular Focus on Open Account Trade ...........................7

Ineffective TBML Prevention Approach ...................................................................................

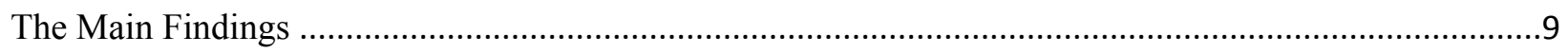

TBML Engine: Small/Medium-Import/Export Business ...........................................................

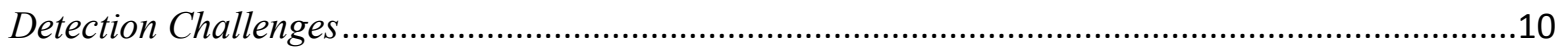

Defensive Reporting ...........................................................................................................

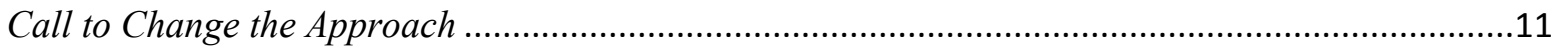

Perspective on the UK Government's Attitude towards Money Laundering Challenges ...................11

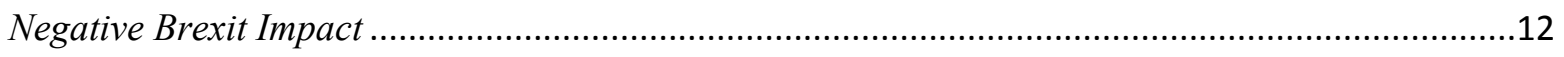

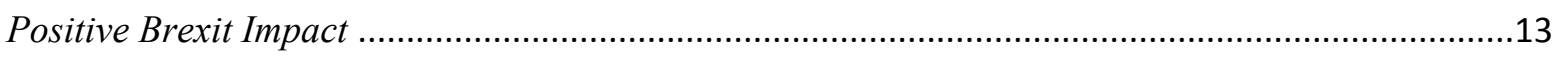

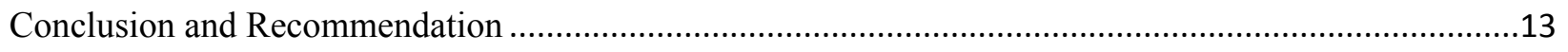

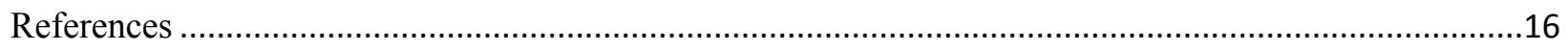




\title{
Journal Article
}

\begin{abstract}
Purpose - This paper provides unique empirical findings exploring the impact of the UK's postBrexit Economic Strategy to boost trade with developing countries on the UK banking sector's ability to manage trade-based money laundering risks.

Design/methodology/approach - Exploratory research design that utilised structured literature review, followed by semi-structured interviews with key subject matter experts employed by large UK banks.
\end{abstract}

Findings - Both banks and law enforcement struggle to prioritise TBML intelligence discovery due to deficient skills, resources, technology, and lack of strong regulatory stimulus. The regulated sector calls for the UK Anti-Money Laundering (AML) reform that would better incentivise TBML deterrence, yet the Government underestimates the money laundering risks while trading with high-risk jurisdictions post-Brexit.

Research limitations/implications - The findings are based on a small sample of six semistructured interviews with difficult to access population of key subject matter experts. Despite the small sample, participants provided well-articulated and informed insights.

Practical implications - The UK's post-Brexit Economic Strategy to boost trade with developing countries downplays the TBML risks it carries. The findings should alert UK banks, law enforcement, and the Government who will collectively bear the responsibility to effectively manage TBML while enabling smooth trading.

Originality/value - The research provides unique perceptions of UK banks' senior subject matter experts on managing TBML threats from opportunistic criminals.

Keywords - Brexit, Proceeds of Crime, Trade-Based Money Laundering, UK Banking, Risk, Risk Perception, Risk Management, Regulation, Compliance, Organized Crime

Paper type - Research paper 
Trade-Based Money Laundering (TBML) is used to move illicit value through trade transactions. Global Financial Integrity (2017) estimates that approximately 87 per cent of illicit financial flows from developing countries, between 2005 and 2014, were accomplished through this method. Despite the prevalence of the threat, trading with that block forms an important part of the UK Government's Economic Recovery Strategy post-Brexit.

Transparency International (2017) confirms that the UK will face new corruption risk by increasing trade with developing countries. Lord Ricketts, a former national security adviser, stresses further that the Britons' safety will worsen with the loss of access to many vital European crime databases (Sabbagh, 2020). Even organized crime rings admit that the reshaped UK trade landscape creates opportunistic conditions for their illicit cross border activities (Marinetto, 2018).

The HM Treasury (2017) shares the concerns by calling TBML the greatest area of risk to the UK economy due to the vast sums of criminal funds passing undetected through complex UK corporate vehicles and offshore jurisdictions. UK banks, by the nature of processing billions of pounds for those entities, are perceived as best suited to spot illegitimate trade activities of their customers.

While a lot of research has been done on how Brexit would boost opportunities for British businesses, not much has been written on its potential TBML prevention impact. Majority of the literature centres on defining TBML methods, policies to drive regulatory reforms, and ways to empower countries' Financial Intelligence Units (FIUs). The perspectives of the UK banking compliance departments are voiced in various general publications such as articles and governmental reports, but academically researched knowledge remains underrepresented.

To expand the knowledge, the author conducted qualitative research by interviewing senior TBML experts currently or previously employed at UK banks and holding the responsibility to mitigate banks' propensity to criminal abuse.

This paper provides unique empirical findings exploring the impact of the UK Economic Strategy to boost trade with developing countries on the UK banking sector's ability to mitigate trade-based money laundering risks. The researcher identified three main findings, which together present unique insights into UK banks' readiness to deter opportunistic TBML. The participants expressed that both banks and law enforcement deprioritise TBML intelligence discovery due deficient skills, 
resources, technology, and lack of strong regulatory stimulus. The regulated sector calls for the UK Anti-Money Laundering (AML) reform that would better incentivise TBML deterrence, yet the Government underestimates the risks associated with trading with high-risk jurisdictions post-Brexit.

\section{Methods}

In order to meet the exploratory research purpose, the interpretivist paradigm appeared as the most suitable philosophical stand to inform the research design. Kumar, Talib and Ramayah (2012) advise using the interpretivist exploratory research design when a researcher deals with new complex matters, and wants to better familiarise oneself with the studied topic. Subsequently, qualitative methodology of a structured literature review followed by semi-structured interviews was utilised to obtain multidimensional perspectives.

The author successfully interviewed six TBML subject matter experts. Such senior banking compliance professionals typically work at financial institutions' FIUs departments that deal with highly sensitive data. Moreover, a deep level of expertise required to meet the demands of the job makes those teams relatively small in size. Consequently, nonprobability snowball sampling technique was used to gain access to the participants.

Due to the coronavirus social distancing restrictions phone calls were picked as the primary engagement method. The author designed an interview schedule for consistency in wording and the sequencing of the questions. Although deviations from the schedule happened often, depending on the respondents' experience, some level of standardisation helped in observing patterns in responses.

Despite the findings being based on a small interview sample, they do provide well-articulated and informed insights. All participants obtained higher education, were professionally certified in the AML domain and had at least 15 years on the job experience across many large UK banks. Some had lengthy career backgrounds spanning across law enforcement and banking, thus were able to voice their experiences from both sides. Their roles split as follows:

- Senior Trade Processing Manager

- Two Senior Intelligence Officers with policing background

- Senior TBML Training Provider to banks, law enforcement, and the regulators 
- Senior Compliance Investigator for complex cases with law enforcement background

- Head of Compliance and Financial Crime Risk Strategy

Constructing a representative sample of people who are affected by a very distinctive problem is difficult. Including those with more generic AML understanding, rather than deep TBML knowledge, could make the findings biased towards people with lower domain knowledge and render the findings not valid. Further, Crouch and McKenzie (2006) point that in order for a researcher to gain unique perspective on complex subjects, one must build fruitful relationships with respondents what can only be achieved with small samples.

Most interviewees were willing to share very sensitive information, as long as their anonymity was ensured. The researcher decided to delete any sensitive information that was judged as potentially damaging to the persons or organisations mentioned during the interactions.

The researcher found thematic analysis as the most appropriate method to uncover themes and patterns in response. Braun and Clarke (2013) confirm that the technique is good for small research projects of 6-10 participants. The transcription process allowed the author to gain good understanding of the data collected and to code the responses based on keywords such as risk, regulators, compliance framework, operations, law enforcement, and Brexit. Analysis of each revealed subthemes that focused around the regulatory framework criticism, its negative impact on UK banks' TBML knowledge, resources and technology, as well as the UK Government's oblivious attitude towards the TBML risks with developing countries. The author has also searched for an overarching sentiment with which the responses were provided. Many participants revealed strong frustration with the existing approach to TBML detection. Their quotes are included in the paper to help the readers understand the interviewees' prevailing emotions.

\section{TBML Problem Overview}

\section{Prevalence}

TBML is "the process of disguising the proceeds of crime and moving value through the use of trade transactions in an attempt to legitimize their illicit origins... frequently used in combination with other money laundering techniques to further obscure the money trail” (FATF, 2006, p. i). Its use became more attractive with the growth of world trade that in 2018 was valued at \$20 trillion (Byrne, 2020). The United Nations (2020) point, however, that the coronavirus outbreak and 
changing trade relationships between many countries are expected to contract the global economic growth for some time.

The Europol (2020) stresses that despite the expected recession, organized criminals will thrive by exploiting vulnerable people and businesses. Italian Mafia, for example, has already approached cash struggling businesses with candid offers to pull them through the economic instability (Tondo, 2020). We can expect some of those businesses to eventually resurface as vehicles in complex trade-based money laundering schemes.

One of Italy's most respected anti-mafia prosecutors, Nicola Gratteri, warns about the UK's role in facilitating international movement of the illicit funds (Forster, 2017). He points that post-Brexit, British trade bureaucracy and complex corporate structures will become even more popular as vehicles for the sole purpose of processing dirty money (Forster, 2017).

Susceptible Industries and Businesses with Particular Focus on Fishing

FATF (Financial Action Task Force) and Egmont Group (2020) caution that any business could get complacent in TBML, but the most susceptible operated in:

- Gold, precious metals, and minerals

- Auto parts and vehicles

- Agricultural products and foodstuffs

- Clothing and second-hand textiles

- Portable electronics (mobile phones, laptops, etc.)

The World Wildlife Fund (2020) expands the list to include companies trading in natural resources such as timber, live animals, and fish. Fish is a striking topic given its central role in the UK-EU Brexit negotiation process.

The United Nations Office on Drugs and Crime (2020) stats that illegal fishing is worth between \$10-23.5 billion annually for the transnational criminals who use fishing vessels not only to move fish, but also drugs, firearm, animals, and trafficked human beings. National Crime Agency, for example, arrested 72 people in November 2020 on a 30-metre fishing boat off the coast of Great Yarmouth in East Anglia in a people-smuggling investigation (Reuters, 2020). 
Opportunistic criminals are expected to take advantage of the new UK-EU trade deal that already creates economic disadvantages for many fishermen. For example, Scottish fishermen in fear for their future earning could fall prey to criminals wanting to use their boats and high seas knowledge in exchange for an alternative income (BBC, 2021). The risk of that happening is rather high. The United Nations Office on Drugs and Crime (2020) highlights that due to the uncoordinated cross-border policing initiatives, the finishing industry is considered as low risk and high-profit environment for criminals. The organisation, therefore, strongly advocates for the increased focus on identifying organised crime groups who both commit predicate offences on the water and those who profit from those activates (The United Nations Office on Drugs and Crime, 2020)

Susceptible Trade Finance Products with Particular Focus on Open Account Trade UK Banks are also instrumental vessels in facilitating international trade by not only processing billions of pounds in associated transactions but also by offering a variety of trade finance options. Cowdell (2015) grants special attention to an open account trade method, also known as buy-nowpay-later agreements, that finances 80 per cent of the global trade despite being most vulnerable to money laundering. Soudijn (2014) explains that with such arrangement, the buyer and the seller agree on a clean or netting payment through the banking system without the need for burdensome documentation detailing the purpose of the transaction or all the involved actors.

The Bankers Association for Finance and Trade (2017) advises banks to pay special attention to open trade transactions involving developing countries. FATF (2020) adds, however, that telling good transactions from the bad demands an impossible task of obtaining customer verification data residing in regions with strict data privacy laws, poor money-laundering controls, or lacking in international cooperation. Furthermore, those payments are typically spread across many global financial institutions making the TBML detection for an individual bank very difficult (FATF, 2020).

\section{Ineffective TBML Prevention Approach}

Timely suspicious activity identification, however, is mandated on all the regulated institutions under the global AML requirements. Failure is punishable with large fines and potentially tarnished reputation. For example, Danske Bank A/S is expected to be fined $\$ 2$ billion by authorities in Denmark, the United States, and the United Kingdom for being used in Europe's biggest money-laundering scandal amounting to $\$ 223$ billion in suspicious transactions (Schwartzkopff, 2020). 
Large banks take the risk of being implicated in such scandals very seriously, thus each spends around $\$ 500$ million a year to mitigate money laundering (KPMG, 2020). A large portion of that spend goes towards advanced regulatory compliance technologies, such as know your customer onbarding, watchlists and sanctions screening, ongoing customer due diligence, transaction monitoring, holistic customer profiling, and analytics tools that include artificial intelligence/machine learning, network analytics, and natural language processing.

As innovative as those solutions sound, their functionality is inherently limited by the uncertainty around the regulatory approval. Vendors, in fear of getting the expectations wrong, rarely propose concepts that challenge the current compliance approaches. SAS (2019), one of the leading AML technology provider, explains that while machine learning models are fantastic at finding money laundering patterns, their output has been considered too complex for non-techy regulators to understand and thus accept as better compliance practise.

Such conservative attitude towards bold AML ideas, however, empowers criminals to run free. According to the International Monetary Fund, the money laundering economy is worth close to five per cent of the world's gross domestic product (Weeks-Brown, 2018). The Europol (2017) and the European Parliament (2018) further point out that about one per cent of the criminal activities are ever spotted, reported, and criminal profits confiscated. Faced with those gloomy statistics, the European Banking Federation urgently calls for more progressive thinking aimed at AML approach redesign (Wass, 2020).

\section{The Main Findings}

\section{TBML Engine: Small/Medium-Import/Export Business}

The participants were asked about their personal experiences with detecting and deterring TBML under the existing AML regulatory framework. All pointed towards the difficulty in identifying the crime as it spans across numerous global predicate offences such as fraud, human trafficking, drug trade, terrorism financing, and capital flight. They expressed particular concerns with monitoring small and medium-size companies trading with Asia, Latin America and Sub-Sahara regions that are known for large illicit outflows.

Participants highlighted that the added challenge rested with the inadequate number of relationship managers tasked with thoroughly understanding their client's business activities. Participant 1, a 


\section{Detection Challenges}

All participants agreed that spotting TBML demands cross-departmental collaboration ranging from account managers, trade processing staff, and financial intelligence units of compliance. Each possesses a unique outlook that can be strengthened with knowledge sharing and training. The difficulty, however, rests in taking staff for training without impacting their targets and key performance indicators (KPIs). Participant 1 pointed that "finding suspicious activities is never one of the KPIs".

The banking compliance employees were generally considered more knowledgeable about TBML then the law enforcement investigators. The participants blamed deficient budget, resources, time, and constantly changing Home Office objectives as big contributing factors. "There isn't [simply] an encouragement to chase down the lines of inquiries", said Participant 6, a senior compliance 
investigator, who left law enforcement due to the frustrating lack of focus on investigating economic crimes.

Others confirmed that the most knowledgeable AML workforce was now employed in the private sector with much better pay and career progression. They also pointed that Brexit and post coronavirus budgetary austerity was expected to further deepen the skill gap and thus negatively impact law enforcement's ability to tackle economic crimes. The participants agreed that banks, therefore, ought to expect further burden with policing TBML and its predicate offences.

\section{Defensive Reporting}

The interviewees pointed that banks felt more incentivised by the Government's AML regulations to protect themselves against fines and reputational damages, than to deter criminal behaviour. They explained that this approach resulted in banks filing defensive suspicious activity reports (SARs) that simply overload law enforcement with low-quality information. Frustrated Participant 3, a senior intelligence officer, expressed that "a hot and heavy breath of the regulator down the back of the people working in compliance advisory and investigations pushes them to defensive SAR reporting".

Joint Money Laundering Intelligence Taskforce (JMLIT) was mentioned as a more effective approach to detecting and deterring TBML. JMLIT is a partnership between law enforcement and financial institutions to exchange intelligence relating to high-end money laundering schemes which are complex, multi-institutional, and multi-jurisdictional (NCA, 2020). Participant 4, a senior intelligence officer, called JMLIT as a "ground breaking idea ...that make banks much more dynamic in interacting one with another around suspicious activities". Participant 3, also senior intelligence officer, emphasised that "the cases and SARs that come of JMLIT are far higher in quality than from any individual bank, but they are currently just a drop in the ocean of more than 400,000 SARs reported by UK entities".

\section{Call to Change the Approach}

Conversations on the JMLIT framework revealed, however, that most banks were very reliant on law enforcement to alert them to TBML threats despite their poor expertise on the subject. Naheem (2018) confirms that in many cases, without initial law enforcement involvement, the banking sector is very likely to miss TBML wrongdoings. He adds that even the UK Financial Intelligence 
Unit relies heavily on local law enforcement and the Europol to highlight potential TBML case (Naheem, 2018).

The practice was called peculiar by a few participants. They explained that law enforcement did not have the skills or resources to prioritise TBML investigations and would rather go after easier crimes that contribute to targets for successfully closed cases. Participant 2 said that "TBML is just too costly to investigate and even harder to prosecute".

Some participants expressed frustration with the banking sector's constant reliance on law enforcement to feed them intelligence on the investigated cases. Participant 2 stressed that "we cannot prosecute enough people to change the world... The problem exists because there is high demand and it makes too much money... change [that] paradigm, and you win". Participant 4 also resounded the sentiment by noting that many banks engage in one way conversations with law enforcement where they only ask for specific intelligence on certain customers. They could be, rather, more proactive in their approach by working with law enforcement to build a bigger picture of the criminal network they could be unknowingly banking.

\section{Perspective on the UK Government's Attitude towards Money Laundering Challenges}

The UK Government appears to be less convinced with the need to change the current AML prevention approach. Many participants attributed the attitude to the UK's glowing 2018 FATF mutual evaluation report. The country was described as having a well-developed and robust regime to effectively combat money laundering and terrorist financing (FATF, 2018). Some participants expressed strong disappointment with those results. They critiqued that FATF narrowly focused on assessing if AML frameworks and legislations were in place, and not if they were effective. Frustrated Participant 6 pointed that "it was as if you were reading about a different country...that is not what happens here... who managed to convince the people doing the evaluation and show them that it works?... of course it does not!”. Transparency International (2018) also challenged the FATF assessment by calling out the UK's notorious failures in preventing $£ 100$ billion in illicit funds impacting the country each year.

In its 2019 report on economic crime, the Treasury Committee (2019) also urged the UK Government to take a tougher stand in the fight against economic crime, particularly as the UK enters trade negotiations with high-risk countries post-Brexit. The Government is yet to provide a formal response to how it is going to address the issue. 


\section{Negative Brexit Impact}

The topic of Brexit impact on TBML caused unease amongst the participants. They were particularly concerned with the UK Government agencies' losing access to the European crime databases. Morris (2020) confirms that under the new UK-EU trade deal, the security co-operation would no longer be based on "real-time" access. Sharma (2020), adds that membership in Europol, Eurojust, and the European Arrest Warrant would be suspended. Casciani (2020) further stresses that losing those rights is very detrimental to the UK law enforcement who, for example, use just the Schengen Information System around half a billion times every year.

Most interviewees anticipated that the economic crime prevention topic would not get much attention during the initial UK-EU trade deal negotiations. Worried Participant 2 stated that "asking for more resources or extra budget has always been a very difficult conversation...with the recession and Brexit combined, it is now going to become even harder". Participant 3 pointed that Brexit and post coronavirus recession was going to push the Government to further deprioritize the economic crimes prevention, particularly when risky business brings money into the country.

Boris Johnson's plan to establish ten free trade zones to aid the economic recovery was listed as one example of the Government's potential relaxing attitude towards dirty money. Free trade zones benefit from different customs duties and supervision to the rest of a country's territory making policing criminal activity harder (Basquill, 2020). The participants articulated that banks played a crucial role in ensuring the smooth flow of the business through trade zones, but burdening them with extra AML regulations would make it too expensive for the banks to service. Participant 2 explained that "[AML regulations] are counterintuitive to stimulating business from those zones", and Participant 3 added that "AML will [therefore] take a second place of an afterthought".

\section{Positive Brexit Impact}

Some participants, however, saw Brexit as an opportunity for the UK Government to take a firmer stance on protecting the country from money laundering schemes. They pointed that the UK, in response to the new data access limitations and weakened international investigation assistance, had to redesign its AML approach to suite the new political environment. 
Participant 3 compared the current AML approach to a "blame game" explaining that law enforcement blames banks for poor quality reporting, banks blame the regulators for restrictive covenants in detecting crimes, regulators blame FATF for their narrow regulatory guidelines that influence the European AML Directives. The participant summarised that "we make sure that everybody has somebody else to blame. I cannot change because they cannot change",

Tom Keatinge (2019) form RUSI particularly critiques FATF as one of the intuitions responsible for the ineffective global compliance measures. He expanded that FATF failed at applying its own mantra of a 'risk-based approach' and assessed all countries with the uniform framework against the AML requirements and not how effective they were in detecting the crime (Keatinge, 2019).

As part of the necessary UK AML approach redesign, the country could champion change in the way evaluations are done on large economies whose AML failures carry global consequences. Keatinge (2019) agrees that a more effective method would be to conduct a higher frequency of targeted reviews on systemically important jurisdictions such as the UK. Naturally, this would put more spotlight on the country's AML measures, but also highlight practical improvements delivering better results that could be replicated by other global financial centres. Further, insights derived from such approach would help prioritise emerging risks and prompt collaboration with the developing jurisdictions on addressing the predicate crimes before further engaging in trade.

\section{Conclusion and Recommendation}

The HM Treasury considers TBML as the greatest area of risk to the UK economy due to the vast sums of undetected criminal proceeds passing undetected through the UK banking system. A large portion of those funds originates in the developing countries with which the UK plans to strike new trade agreements post-Brexit. The Government appears, however, to downplay the associated risk assuming that the country's current AML regime is fit to withstand the threat.

The researcher conducted a small-scale pilot study to explore the impact of the UK Economic Strategy to boost trade with developing countries post-Brexit on the UK banking sector's ability to mitigate trade-based money laundering risks.

The author applied interpretivist paradigm to inform the exploratory research design that utilised qualitative methodology of a structured literature review followed by semi-structured interviews. 
The literature revealed that little has been written on the impact Brexit might have on the UK banks' TBML deterrence preparedness, however, it did provide a good background to understanding the potential scale and the underlying causes of the problem.

TBML gained popularity due to the growth of the world trade and despite the contracting global economic output, triggered by Brexit and coronavirus pandemic, criminal enterprises are still predicted to thrive. The UK is highlighted as a major enabler for their illicit growth due to the country's bureaucracy and ease in setting up complex corporate structures.

Criminals have a vast array of businesses and sectors that they could readily use for their TBML schemes. Fishing industry does not appear like an obvious choice, but it is frequently used by transnational criminals to move various illegal goods across borders. The sector's attractiveness is predicted to increase due to the new UK-EU trade deal that threatens fishermen on both sides with big financial loses. Criminals could seize the opportunity to exploit fishermen's vulnerable state by offering an alternative deployment of their boats and the high seas knowledge.

Banks are yet another important vessel in moving goods around. They not only enable secure processing of the associated transactions but also help to finance trade. The vast majority of international trade is financed on open account terms due to the convenience and limited documentation required. The same benefits, however, make it particularly difficult for UK banks to effectively deter money laundering abuse.

To better understand those challenges and the Brexit impact, the author interviewed senior subject matter experts currently or previously employed at large UK banks.

All participants pointed towards the difficulty in identifying the crime on open account terms. They expressed particular concerns with monitoring small/medium-import/export companies trading with regions known for large illicit outflows. Lacking strong regulatory stimulus to manage TBML risks paired with poor knowledge, resources and technology added to the challenge for both banks and law enforcement alike.

Participants called for a regulatory change that would better incentivise prioritising TBML deterrence, particularly that the country faces weakened collaboration from the European countries post-Brexit. 
The UK Government, however, seems to trust that the country's money laundering prevention functions well and Brexit is not a concern. The interviewees worried further that the looming recession would only push the Government to continue to deprioritize money laundering prevention, particularly when risky business brings money into the country.

Some participants, however, saw Brexit as an opportunity for the UK Government to take a firmer stance on money laundering prevention. The country, being an important financial centre, could redesigning its regulatory approach that not only protects the UK, but also guides other global financial markets in developing more effective controls. For example, conducting a higher frequency of targeted AML effectiveness reviews could provide insights on how to prioritise emerging risks and prompt collaboration with the developing countries on addressing predicate crimes before further engaging in trade. If done well, it could prompt other global financial centres to replicate the approach; the approach where large economics facilitate international growth in trade through effective money laundering controls. 


\section{References}

1. The Bankers Association for Finance and Trade. (2017). Combating Trade Based Money Laundering: Rethinking the Approach. Retrieved from https://baft.org/docs/defaultsource/marketing-documents/baft17_tmbl_paper.pdf

2. Basquill, J. (2020, October 13). Banks face financial crime headache over free trade zones. Global Trade Review. Retrieved from https://www.gtreview.com/news/europe/banks-facefinancial-crime-headache-over-free-trade-zones/

3. BBC. (2021, January 15). Scottish fishermen 'sailing to Denmark to land catch'. BBC News. Retrieved from https://www.bbc.co.uk/news/business-55669168

4. Braun, V., Clarke, V. (2013). Successful Qualitative Research: A Practical Guide for Beginners. London: SAGE. Retrieved from https://books.google.co.uk/books?id=nYMQAgAAQBAJ\&printsec=frontcover\&source=gbs ge summary $\mathrm{r} \& \mathrm{cad}=0 \# \mathrm{v}=$ onepage $\& \mathrm{q} \& \mathrm{f}=$ false

5. Byrne, D. (2020, December 9). Criminal organisation used international trade to disguise $\$ 400+$ million in dirty money; FATF warns that trade-based money laundering poses serious threat. AML Intelligence. Retrieved from https://amlintelligence.com/2020/12/criminalorganisation-used-international-trade-to-disguise-400-million-in-dirty-money-fatf-warnsthat-trade-based-money-laundering-poses-serious-threat/

6. Casciani, D. (2020, December 17). Brexit: What does it mean for security in the UK? BBC News. Retrieved from https://www.bbc.co.uk/news/explainers-55333543

7. Cowdell P. (2015). Guide to International Trade and Finance. Canterbury, UK: ifs University College

8. Crouch, M., McKenzie, H. (2006). The logic of small samples in interview-based qualitative research. Journal of Social Science Information, 45(4), 483-499. doi.org/10.1177/0539018406069584

9. Emerald Publishing (2020). Journal of Money Laundering Control. Retrieved from https://www.emeraldgrouppublishing.com/journal/jmlc\#indexing-and-rankings

10. The European Parliament. (2018, October 1). Criminal proceeds: making it easier to freeze and confiscate across the EU. The European Parliament News. Retrieved from https://www.europarl.europa.eu/news/en/headlines/security/20180927STO14535/criminalproceeds-making-it-easier-to-freeze-and-confiscate-across-the-eu 
11. The Europol (2020, April 20). Beyond the Pandemic - What will the Criminal Landscape look like after COVID-19? Europol. Retrieved from https://www.europol.europa.eu/newsroom/news/beyond-pandemic-what-will-criminallandscape-look-after-covid-19

12. The Europol. (2017). From Suspicion to Action. Retrieved from file://C:/Users/User/Downloads/q1-01-17-932-en-c_pf_final\%20(3).pdf

13. FATF and Egmont Group. (2020). Trade-based Money Laundering: Trends and Developments. Retrieved from http://www.fatfgafi.org/publications/methodsandtrends/documents/trade-based-money-laundering-trendsand-developments.html

14. FATF. (2018). Anti-money laundering and counter-terrorist financing measures. United Kingdom. Retrieved from https://www.fatfgafi.org/media/fatf/documents/reports/mer4/MER-United-Kingdom-2018.pdf

15. FATF. (2006). Trade-Based Money Laundering. Retrieved from https://www.fatfgafi.org/publications/methodsandtrends/documents/trade-basedmoneylaundering.html

16. Forster, K. (2017, April 4). Brexit could help Italian mafia create 'truly dangerous' situation, warns public prosecutor. Independent. Retrieved from https://www.independent.co.uk/news/world/europe/brexit-mafia-italy-money-launderingnicola-gratteri-organised-crime-financial-london-uk-regulations-a 7666171.html

17. Global Financial Integrity. (2017). Illicit Financial Flows to and from Developing Countries: 2005-2014. Retrieved from https://www.gfintegrity.org/wp-content/uploads/2017/05/GFIIFF-Report-2017 final.pdf

18. The HM Treasury and Home Office. (2017). National risk assessment of money laundering and terrorist financing 2017. Retrieved from https://assets.publishing.service.gov.uk/government/uploads/system/uploads/attachment data /file/655198/National_risk_assessment_of_money_laundering_and terrorist_financing_2017 pdf_web.pdf

19. Keatinge, T. (2019, October 23). It's Time to Reform and Refocus the Financial Action Task Force. RUSI. Retrieved from https://rusi.org/commentary/it\%E2\%80\%99s-time-reform-andrefocus-financial-action-task-force 
20. KPMG. (2020). Combating financial crime. Retrieved from https://home.kpmg/xx/en/home/insights/2019/03/combating-financial-crime-fs.html

21. Kumar, M., Talib, S.A., Ramayah, T. (2012). Business Research Methods. UK: Oxford University Press. Retrieved from https://www.oxfordfajar.com.my/highereducation/business-research-methods/529

22. Marinetto, M. (2018, March 12). What Britain's organised criminals think of Brexit. NewStatesman. Retrieved from https://www.newstatesman.com/politics/uk/2018/03/whatbritain-s-organised-criminals-think-brexit

23. Morris, Ch. (2020, December 28). Brexit deal: What is in it? BBC News. Retrieved from https://www.bbc.co.uk/news/55252388

24. Naheem, M.A. (2018). TBML suspicious activity reports - a financial intelligence unit perspective. Journal of Financial Crime, 25(3), 721-733. doi:10.1108/JFC-10-2016-0064.

25. NCA. (2020). National Economic Crime Centre. Retrieved from https://www.nationalcrimeagency.gov.uk/what-we-do/national-economic-crime-centre

26. Reuters. (2020, November 18). UK arrests 72 people on fishing boat in people-smuggling investigation. Reuters. Retrieved from https://uk.reuters.com/article/uk-britain-crimesmuggling/uk-arrests-72-people-on-fishing-boat-in-people-smuggling-investigationidUKKBN27Y2PC

27. Sabbagh, D. (2020, December 11). No-deal Brexit would make Britons less safe, ex-national security adviser says. The Guardian. Retrieved from https://www.theguardian.com/politics/2020/dec/11/no-deal-brexit-would-make-britons-lesssafe-ex-national-security-adviser-says

28. SAS. (2019). How AI and Machine Learning Are Redefining Anti-Money Laundering. Retrieved from https://www.sas.com/en/whitepapers/ai-machine-learning-redefining-aml110762.html

29. Schwartzkopff, F. (2020, January 3). Danske Faces \$2 Billion in Fines for Laundering Case, Jyske Says. Bloomberg. Retrieved from https://www.bloomberg.com/news/articles/2020-01$\underline{03 / \text { danske-faces-2-billion-in-fines-for-laundering-case-jyske-says }}$

30. Sharma, R. (2020, December 25). What Brexit trade deal means for security as UK exits Europol, SIS2 and the European Arrest Warrant. iNews. Retrieved from https://inews.co.uk/news/brexit/brexit-deal-impacts-uk-security-europol-sis2-808461 
31. Soudijn, M. (2014). A critical approach to trade-based money laundering. Journal of Money Laundering Control. 17(2), 230-242. doi:10.1108/JMLC-01-2013-0001

32. Tondo, L. (2020, April 10). Mafia distributes food to Italy's struggling residents. The Guardian. Retrieved from https:/www.theguardian.com/world/2020/apr/10/mafiadistributes-food-to-italys-struggling-residents

33. Transparency International. (2017, May 11). Build Anti-corruption Measures into all PostBrexit Trade Deal. Retrieved from https://www.transparency.org.uk/build-anti-corruptionmeasures-all-post-brexit-trade-deals

34. Transparency International. (2018, December 7). UK’s £100 Billion Dirty money Problem must be confronted following international Review. Retrieved from https://www.transparency.org.uk/uk-s-100-billion-dirty-money-problem-must-be-confrontedfollowing-international-review

35. The Treasury Committee. (2019). Economic Crime - Anti-money laundering supervision and sanctions implementations. Retrieved from https://publications.parliament.uk/pa/cm201719/cmselect/cmtreasy/2010/201003.htm\#_idTe xtAnchor000

36. The United Nations Office on Drugs and Crime. (2020). Fisheries Crime. Retrieved from https://www.unodc.org/documents/aboutunodc/Campaigns/Fisheries/focus_sheet PRINT.pdf

37. The United Nations. (2020). Impact of the COVID-19. Pandemic on the Trade and Development. Transitioning to a New Normal. Retrieved from https://unctad.org/system/files/official-document/osg2020d1_en.pdf

38. Wass, S. (2020, March 10). European banks call for 'critical review' of anti-moneylaundering regime. $S \& P$ Global Market Intelligence. Retrieved from https://www.spglobal.com/marketintelligence/en/news-insights/latest-newsheadlines/european-banks-call-for-critical-review-of-anti-money-laundering-regime$\underline{57487567}$

39. Weeks-Brown, R. (2018, December). Countries are advancing efforts to stop criminals from laundering their trillions. International Monetary Fund. Retrieved from https://www.imf.org/external/pubs/ft/fandd/2018/12/imf-anti-money-laundering-andeconomic-stability-straight.htm 
40. The World Wildlife Fund. (2020). Illegal Fishing. Retrieved from https://www.worldwildlife.org/threats/illegal-fishing 